Весна Половина

Универзитет у Београду

Филолошки факултет

e-mail: polovina.v@gmail.com

https://doi.org/10.18485/ai_san_o_gradu.2020.ch11

81 '363

Оригинални научни рад

\title{
О ГРАДУ, МАШТИ И СНОВИМА
}

У раду се анализирају два типа текстова која на различите начине приказују град као вишесмислену категорију: стручни текстови из области архитектуре и неки књижевни текстови. У текстовима који се баве градом као предметом стручне анализе, јављају се често поетизоване слике града: „град по мери човека“, урбанистичка „мрежа“, „паметни град“ и сл., док се у књижевним текстовима град поставља као метафора и позадина са изразито људском димензијом и значењем. Циљ ове анализе је да покаже сличности и разлике у начину како ова два типа текста показују или досежу степене апстракције у повезивању града са људском маштом и сновима о граду који се испољавају кроз језичке изразе о граду и човеку.

Кључне речи: град, машта, снови, песме, проза, архитектура.

Бескрајни су начини на које се о градовима машта и како их видимо: као фрагменте, сенке, звукове, слике, емоције, мисаоне рефлексије, као језик којим је обасут. Готово сваки човек, а поготово уметници, писци, песници, сликари, музичари, имају своје визије и снове, маштања о граду. Град, што је и природно, никада није само скуп грађевина, јер су то онда мртви градо- 
ви, остаци несталих градови. Градови су увек и људи који живе у њима или долазе и одлазе из њих. Како се посматра град зависи од много чега, али као антропоцентрична визија, он је увек виђен у неким својим деловима или елементима. Како каже Исидора Секулић: „Паланка је вечна форма људског друштва, вечна и свугде присутна. Велики градови су састављени из многобројних паланака, великоварошка гробља из паланачких гробаља. Тамо и тамо имамо множину малих кругова рођака и познаника, који су живели, разговарали, везивали се и истребљивали се на начине како се то ради по паланкама, кроз односе и сударе малих калибара“. (Секулић, 1977:23)

Ове речи Исидоре Секулић можда најбоље илуструју оно што желимо да покажемо анализирајући различите типове текстова о граду, машти и сновима, управо зато што истиче вишеслојевитост којом перцепирамо неки град, али и како говоримо о градовима. Животи људи су уткани у њега, породице, сарадници на послу, пријатељства, љубави, генерације, приче, историја, митови и легенде. Он је и „форма људског живота“, али и састављен од низа појединачних судбина и судбина друштва. Јер, град није хомогена ствар, у њу учитавамо низ нових значења: он је најмање објекат који подразумева опис, а, како ће показати текстови које анализирамо, и ствар емоција, песничког надахнућа, имагинације и снова. Текстови које смо одабрали су разноврсни у следећем смислу - говоре о граду са различитих аспеката, емотивно-лирских или стручних, из домена архитектуре, а текстови су са српског и енглеског говорног подручја, без посебних претензија ка културолошком поређењу, осим кад је то баш неопходно.

Започећемо опаскама које се односе на популарну културу, па преко уметничке поезије и прозе, до тек- 
стова које су на овај или онај начин ауторизовали архитекте, тражећи у њима заједничко, а што говори о имагинацији, сновима, а истаћи ћемо и понеке разлике које сматрамо културолошки битним: шта је то што ограничава или дефинише разлике у маштању о граду. Под културолошким разликама овде подразумевамо не националне, већ хоризонталну социјалну раслојеност на популарну музику, уметничку поезију и прозу, стручне текстове. То је наш примарни циљ, а одбир таквих текстова на српском и на енглеском је пре свега условљен настојањем да се пронађе сличност у разноликости, док је лингвокултуролошко поређење на та два језика од секундарног значаја, јер би оно захтевало друкчији приступ.

Популарне песме посвећене градовима. Вероватно бисмо могли да пропутујемо свет када бисмо хтели да посетимо све градове за које су написани стихови, па и популарне песме које се певају о њима. Не улазећи у вредновање таквих текстова (неки су сигурно изузетне вредности, а неки се своде на шаблонске и баналне стихове) нас је интересовало како се о градовима може певати у популарној музици, сматрајући то једним могућим типом текста, и то оним који су припадницима једне културе често много познатији од других типова.

Када бисмо требали да дамо заједничка обележја виђења града у популарним песамама то би могло да буде: „јединствен“, „непоновљив“, „вечан“. Прво се осврћемо на позитивно усмерене песме, и можемо их назвати неком врстом „ода“ градовима или локал-патриотским песмама посвећеним једном граду. Такве су оне које су и написане да прославе неки град, често поводом неког важног догађаја или датума. Многе популарне песме о Београду и другим градовима наше земље готово су шаблонски написане. Заједничка нит 
је готово свима (познатијим) љубав коју аутори песама $^{1}$ гаје према граду, симболу не само завичаја него и вечне љубави, пријатељства, душе и срца. Он је вечан: вековима чуваш бео лик, За тебе к'о да стоји време / ти живиш срием увек млад (Beograde, Đ. Marjanović i D. Jakšić, 1963), Слободом древни граде буди горд... Београде, Београде, ко суние сјаш, горди граде наш, вечно наш („Химна Београду“, Танасије Младеновић, Миховил Логар, 1944). Чини се да су „срце“ и „душа“ основа емоција које се гаје према граду, али и које град „показује“: Али нигде, нигде, не пронађох / То што има мој вољени град... Мој Београд срце има / И у срцу љубав чисту (Мој драги Београде, Лола Новаковић, Бора Савић, 1962).

Типичан пример песме написане поводом значајног догађаја је позната песма „Барселона“, написана поводом номинације тог града за олимпијске игре 1992. (Фреди Меркјури, Марк Мелон, 1987), у којој слављеничку музику прате речи дивљења и усхићења. Већ прва два стиха (на енглеском и шпанском) односе се на сан и надања о сусрету са љубави у том прелепом, величанственом граду: I had this perfect dream, Un sueno me envolvio, и као што је прелепа његова љубав: The moment that you stepped in the room / You took my breath away, такав је град: Such a beautiful horizon / Like a jewel in the sun. И опет, прошлост која се помиње о незаборавном сусрету, повезује се с будућношћу: And if God is willing / We will meet again, и пријатељство ће бити вечито.

Наравно, нису све песме популарне музике овако позитивно оријентисане, а личне везе и емоције према граду, иако чврсте и вечне, обухваћене су и сетом према

1 Већина текстова песама, као и изведбе су доступни на бројним сајтовима на интернету: нпр. https://tekstovi-pesama.com/, https://tekstovipesama.net/, на сајту YouTube, и сл. 
неким прошлим данима. Новије песме, чини се, више се везују за емотивна сећања аутора, за љубав у прошлости, а град постаје темељ таквих успомена на вољену: April u Beogradu uzaludno traži / Usne jedne djevojke, на другове и неко претходног доба: April u Beogradu jedno prošlo doba / nosim ga u mislima iz vojničkih soba (Кopнелије Ковач, 1975), или се спомињу слике, успомене на неке кратке моменте у граду: Памтиш ли још наша jympa... ноћu/, док су чари града неодређеније: има нечег на том небу / само твоје бели граде, а пријатељи и љубави су остали у прошлости: Њему је свуда расута душа / по иеелом свету деияа и луди (Владимир Марковић и Петар Лазић, 1995).

Даља разматрања песама популарне музике свакако би показала специфичности које се у бројним песмама, макар и релативно шаблонски написаним, јављају, али ћемо овде само као илустрацију показати такву могућност кроз стихове британског музичара Марка Кнопфлера (2015). У једној његовој балади о сицилијанском граду Таормини, уз последњи стих у свакој строфи (истовремено и наслов песме): Looking down upon the lights of Taormina, он се, слично као и у горе поменутим песмама, сећа своје љубави према једној девојци, а тај детаљ из „личне прошлости“ асоцира га на прошлост града Таормине још из античких времена. Тако ствара паралелу кроз изразе везане за своју прошлост: Seems like another lifetime / She used to call him her sweet senor, ca маштом о будућности: Maybe in another lifetime / On a pathway to the sea / Maybe there they'll be, али и са својим концертом одржаним у арени Таормине: Ten thousand voices roared in the arena, да би у последњој строфи повезао и себе и своју љубав са античком историјом: the chimes of history, Ancient dreams, the mists of antiquity.

Иако разноврсне, и у зависности не само од града и 
његових митова или прича, већ пре свега од повода због којих су написане (могу бити за неки филм, поводом неког несретног догађаја који је погодио град, итд.), њИхова везаност баш за појединачни град, за појединачну успомену, најчешће љубав, и отисак у сећањима, чини се да су најчешћа обележја популарних песама. Иако се слични мотиви јављају и у књижевној поезији, језички израз и садржај ту постаје комплекснији и уопштенији.

Град у уметничкој поезији. Док су популарне песме посвећене појединачним, конкретним градовима, са препознатљивим обрисима, и релативно типизираним мотивима, па и начином певања о њима, у књижевној, „озбиљној“ поезији град постаје апстрактнији, па чак и када се име неког града помиње, таква поезија постаје место комплексног размишљања о људској судбини, времену и простору.

Као пример, укратко ћемо навести неке елементе песме „Кад дођеш у било који град“ М. Бећковића (1995). Већ тај први стих говори о нивоу апстракције. Иако у четвртом стиху већ помиње један специфичан град, он је исказан као хипотетички: Ако тај град буде случајно Вальево, па у песми преовлађује идеја о „било којем“ граду. Песник наставља: Ако тај град случајно буде Ваљево / Где сам и ја дошао, ... овај град или било који други град, због успомене постаје: ... само један град / И само једна жена / И један једини дан ..., али, истовремено, умножен у било који град, у вечну слику љубави. Садашњост, прошлост и будућност стапају се у свевременост - будућност: Кад дођеш у било који град, прошлост: ...једини град / У коме си одувек био; да би се на крају песме преточили у готово космичку слику: Јер си већ умро и већ васкрснуо / И поновило се оно што никад није било. Иако је и овде важан мотив љубав и сусрет са једном девојком, простор и време се преплићу кроз сан 
и сећање које се измешта и помера у једном или другом правцу, и тако се стиче флуидна слика неког, било ког, града. Нема ништа од физичке слике града, макар он било који да је, већ само човеков пут, улица, и то кроз звук: кораком који двоструко одјекује/ Твојим и батом још некога. Песма је испуњена сталним контрастима времена и сећања, те цела представља смештање града у вишеслојну конструкцију маште.

Неке савремене песнике можемо назвати и песницима градова, јер по много чему, и по изразу и по тематици, али и по томе што су им песме примарно смештене у градове, њихова поезија је свакако урбана поезија. Тако, рецимо, савремена песникиња Милена Марковић (2011) у готово свим својим песмама дотиче се градова, њихових предграђа и људи. Као пример, наводимо њену песму „Лаку ноћ синови моји“. Иако су и ови њени стихови о љубави према граду и његовом трајању: ја волим тај град / он ми је све дао / он ми је све узео / и још ми даје / и још ми узима / њена молба да се град не руши иако је много ружан, ипак представља место прожето и испреплетано успоменама и животом где се песникиња и сви блиски (мајке, очеви, бабе, синови) памте и овековечују.

Ретко се у поезији, и популарној и озбиљној, осим појединачних слика и звукова, а то могу бити две реке, бат корака, кошава, нека улииа, нека плажа, небо изнад града, пролеће, итд., помиње експлицитно нека зграда или било какав архитектонски призор у правом смислу те речи. Ипак, постоје утопијски митови, легенде, маштања, увек са антропоцентричном основом, који се јављају и везано за архитектуру и изградњу градова. Какав је идеални град који ће остварити и функционалне и естетске циљеве људи који у њему бивају, али и планера града повезује у својој песми британски песник Сајмон Армитиџ (Simon Armitage). На почетку 
песме "A Vision" он каже:

The future was a beautiful place, once,/ Remember the full-blown balsa-wood town/ on public display in the Civic Hll/ The ring-bound sketches, artists' impression, // blueprints of smoked glass and tubular streets/ board-game suburbs [...] They were the plans/all underwritten in the left-hand / of architects - a true, legible script /

Већ први стих повезује будућност и прошлост, а идеални град је постојао на макетама архитеката изложеним у градској већници, укључујући и моделе (фигурице) људи, њихове активности по граду. Све је идеално замишљено, да би у последњој строфи та будућност отишла у ветар, и све те будућности нестале су и пре него што су се оствариле: riding the air with other such future/all unlived and all now fully extinct. И ова поетска слика спаја град и време, идеје архитеката се реализују идеално само као макете и планови, али су нестварни и неоствариви. Иако су друге речи употребљене, у песмама Бећковића и Армитиџа се и смрт и васкрснуће и нестанак и непостојање преплићу као језичко ткање које поприма модерну, узвишену и готово космичку димензију снова посвећену граду.

Архитектура у књижевној прози. На овом месту, пре него што са поезије пређемо на текстове из домена архитектуре, о уској вези између књижевних дела и архитектуре може се пуно говорити. Паланке, касабе, градови, делови градова, град и његова географија, улице и квартови не представљају увек само неутралну позадину прича и романа. Напротив, довољно је подсетити се дела Иве Андрића, у којима цело место попут Травника, или Вишеград са свим својим географским распоном, или Проклета авлија, и сл., нису само пасивне слике, простори на којима се одигравају заплети, већ имају итекако важну симболичну улогу. 
Као пример такве симболике (дела) града у прози навешћемо одломак из Андрићевог дела „На Дрини ћуприја“, у коме се говори како промена изгледа једне грађевине утиче на живот житеља и како је они виде. Промена негира традицију: „У очима свих касабалија, од рођења до смрти, то [караван сарај] и није била обична рушевина него завршетак моста, саставни део касабе као и њихова рођена кућа, и никад нико ни у сну није помислио да би се могло дирнути у стари хан и да би на њему требало ма шта мењати“, па ипак, нова власт аустро-угарске царевине доноси и нову архитектуру, а с њом и нове облике живота:

Za nešto više od godine dana umesto nekadašnjeg karavanseraja od belog kamena, podignuta je visoka glomazna kasarna na sprat, okrečena bledoplavom bojom, pokrivena sivim limom, sa puškarnicama na uglovima. Na proširenom zaravanku vežbali su po vas dan vojnike koji su, uz gromku viku kaplara, mučenički istezali udove i padali licem u prašinu kao nesrećnici. A uveče su sa mnogobrojnih prozora te ružne zgrade odjekivali glasovi nerazumljivih vojničkih pesama, praćeni mundharmonikom [...] Tako je nestalo lepe vezirove zadužbine i tako je kasarna, koju je narod, veran svojim navikama, prozvao Kameniti han, otpočela svoj život na zaravanku pored mosta, u potpunom neskladu sa svim što je okružavalo. (Andrić, 2014:420)

Од „лепе“ до „ружне“ грађевине, од „белог камена“ до „гломазне“ и „бледоплаве“ и „сиве“ боје, са променама и у социјалном погледу, „мученички“, „као несрећници“ војници који настањују нову грађевину певају „неразумљиве“ песме, све то је у потпуном „нескладу“ са дотадашњим изгледом града, па и начином живота људи у касаби. Као да је сама изградња нове зграде донела и почетак новог начина живота, нових призора и неког новог друштва, у сукобу са староседеоцима, ста- 
новницима Вишеграда.

Иако је овај цитат из Андрићевог дела сасвим довољан да илуструје потенцијал уметничке прозе да оживи град и човека, навешћемо још један пример. Пишући о романима Сага о Форсајтима Џона Голсвордија, C. Никитина (Nikitina, 2014) сматра да је подједнако важно говорити о месту и грађевини као симболичком значењу и средству за анализу прозе као што се говори о људској психи, духу времена или неким социјалним вредностима (to ask the questions about the role of home and place as to ask ques tions about class, gender, possessive spirit or Victorian values, which are typically explored in the Saga criticism, (ibid. 63).

У Саги о Форсајтима, када се посматра као билдунгс-роман, сматра Никитина, основна промена и развој ликова у њима дешава се управо у тесној вези са ликом архитекте Босинија и изградњом новог, друкчијег дома за јунакињу, Ирену Форсајт. Тај нови дом је не само нови тип архитектуре ближи модернијим схватањима остваривања склада између грађевине и природе, већ је опозиција према тадашњим, старим начином градње. Наиме, викторијанске куће су биле компартментализоване, свако је знао своје место, мушкарци, жене, деца, и свака просторија па и цела кућа представљале су заштиту од спољашњих утицаја, чувале су социјалну хијерархију и ред. Биле су као маузолеји, без радости, без спонтаности, вечити и непромењиви. А нова кућа и нова архитектура не затвара појединца, он спонтано може комуницирати са породицом, па и слугама, она ствара везе међу људима, не затвара их.

Никитина чак каже на једном месту да је Голсворди својим романима можда допринео савременом схватању циља архитектуре, њене модернизације: „The fact that today we conceive of a home as a confluence of nature 
and nurture, as a matrix of human connections and not a solitary confinement; a portal onto the universe and not a world-proof chamber, is the result of some major historical, cultural and economic shifts which Galsworthy may have contributed to“ (ibid., 65). И даље, на пар места у свом тексту, истиче везу са можда најпознатијим модернистичким архитектом, Френк Лојд Рајтом: „Robin Hill is built, similar to contemporary construction inspired by Frank Lloyd Wright, with the careful consideration of nature in every element of the design" (ibid., 65). Y coцијално-политичком смислу, изразита вертикална социјална раслојеност, доминација виших слојева над нижим, мења се, јер нова архитектура отвара простор, уклања зидове, враћа људе природи, али их враћа и једнакости, сви живе на истој равни, без притисака: „Husband and wife, children and parents seem to reside on the same horizontal plane, on the same level - the realm of mutual love with transparent walls and the ceiling ready to receive and share the light" (ibid., 70).

За разлику од поезије у коме се градитељи, архитекте и задужбинари или наручиоци изградње мало помињу, у прозним књижевним делима њима се често даје много више места. Поставља се питање колико машта и снови о градовима имају своје место у текстовима из архитектуре. Јер, ако је јасно да град у коме људи живе и његови фрагменти и грађевине имају улогу у животима и историји људи, да ли градитељи мисле на исти начин, бар делом у свом маштању? Код архитеката, оних који креирају наше градове, зграде и улице, можемо претпоставити, постоје слични емоционални и концептуални елементи које представљају њихове снове и маштања. Да ли се помињу идеални планови и замисли, а завршава се сасвим друкчије, као што се у поезији сугерише? Односно, питање које нас највише интересује јесте где се у текстовима из области архитектуре јављају искази 
посвећени машти и сновима о градовима.

Као што је за очекивати, у текстовима који се приближавају техничком регистру архитектуре и урбанизма, све мање се даје простора машти, али индивидуалност и лични печат, лик архитекте, имају битну улогу у стварању града и његових грађевина. Ту се машта претвара у визију, у начин на који архитектура може да, евентуално, оствари своје снове, али уз њих придружени и неки друштвени и политички идеали, односно економски и материјални услови.

Текстови из домена архитектуре. О померању перспективе, са маште на реалност, можда најбоље говоре социолошко-историјске студије, каква је, на пример, студија ауторке Ле Норман (Le Normand, 2014), с обзиром на то да је посвећује изградњи нових делова Београда, пре свега Новог Београда, у време социјалистичког раздобља после Другог светског рата. На почетку књиге цитира једног другог аутора (Stanislaus Von Moos-a) и његово поређење утицаја архитеката на стварање градова у односу на друге слојеве друштва, пре свега на власт. У социолошком смислу, архитекте нису ствараоци, већ више извршитељи онога што елита сматра да треба урадити, готово као „кувари“: “the growth and form of cities is not determined by the will of architects, [...], but by socioeconomic forces and interests, institutional patterns, and a conception of progress and efficiency shared by the prevailing elites. Architects merely propose recipes that represent these forms and interests." (ibid., XII).

Иако је ово поређење можда прејако, ипак се, у социјалном погледу, владајућа елита често налази изнад архитекте и његових визија. Елита, власт, имају одлучујућу улогу и њихови „планови за модернизацију“, наметнути естетски и социјални модели ограничавају архитекту. Понекад се проналазе паралеле, па и прекла- 
пања у идеологији архитекте (као уосталом што је случај током читаве људске историје градње) и владајуће социокултурне парадигме, па је и ова студија у основи посвећена заједничкој основи социо-политичких и урбанистичко-архитектонских ставова: „Communists and avant-garde architects, including Le Corbusier, Ernst May, and Karel Teige, shared [...] a conviction that they were "the vehicle for developing and carrying out a 'correct' and scientifically based understanding of the nature of industrial cities" [...] "and how they must be transformed to improve living conditions for all." (ibid., 14). Или: „modernist architects shared the communists' interest in building housing for the masses and, more broadly, their commitment to a more equal and progressive social order" (ibid., 20). У ове две цитиране реченице, кључно је да се идеолошки и политички став везује за комунистичку идеју о изградњи која би била да се створе „што бољи услови за све“, „за масе“, и „за напредни и једнак друштвени поредак“, што свакако одсликава комунистичку идеологију, али доста подсећа и на модернистички идеал архитекте Босинија у Саги о Форсајтима. Осим тога, то имплицитно говори о томе да град и његова здања итекако утичу не само на свакодневни живот, већ и на остваривање социјалне идеологије.

Поред оваквог социо-политичког, идеолошког утицаја, архитекте су подвргнуте финансијским и технолошким ограничењима. Најбољу илустрацију како се њихови снови и маштања ограничавају таквим факторима пружа текст-интервју једног нашег архитекте, Љупка Ћурчића (Алфиревић, 2015). Говорећи о покрету тзв. „брутализма“ у периоду 1950-1970. у Југославији, Ћурчић каже да је тај период за архитекте био посебан, јер се морало градити „брзо и економично“, да „буде трајно и да буде јефтино“, а посебно је важан сле- 
дећи исказ: „И ја бих волео да су моје зграде могле, мислим на судове и СИВ, да буду обложене неким финим каменом. Што да не, било би то много лепше. Међутим, тада нисам могао ни да сањам да од инвеститора тражим тако нешто“ (ibid., 70).

С друге стране, његов рад је био условљен и технологијом, па о примени натур-бетона у тексту говори специфичним термином-метафором: „искрених материјала, примењених у сировом стању, попут натур-бетона и опеке” (ibid., 69) из које произлази „искрена“ архитектура. Дакле, не само да је материјал у сировом облику, већ је „бруталан у визуелном смислу”. На питање о његовом афинитету према одређеном типу објеката које је пројектовао, експлицитно одговара да су његови „афинитети“ били потиснути „сплетом околности“. Тек када је у питању сарадња са другим архитектама, његови искази постају личнији: „Увек сам се трудио да пројектујем функционалне и квалитетне објекте и да уживам, јер архитектуру као посао веома волим. Мислим да је то важно, јер ако се поставе велики захтеви на почетку, онда стваралац самог себе страховито ограничава...”. Дакле, снови и маштања - емотивни изрази попут „искрености“, „уживам“, „волим“, „стваралац“ некако су на периферији исказа овог архитекте, па је јасно да је позиција који је имао у односу на финансијера и наручиоца изградње била одлучујућа, а његова естетика и машта о граду скрајнути. Ипак, он имплицитно пореди своје пројекте и новије, модерније, јер каже да „брутализам“ у архитектури није престао чак ни данас, већ „и неки други материјал може да буде бруталан у визуелном смислу. [...] све ове монструозно велике грађевине урађене у стаклу“. Али зато такође напомиње како је настојао да „оплемени“, оживи објекат, да се над грађевини „појави обиље сенки“, „ублажи 
боја бетона“ и сл., што показује да се и под социо-економским ограничењима није сасвим угасила перцепција зграда које треба да буду и естетски оживљене, напротив, може се схватити, да чак и под тешким ограничењима, овај архитект проналази бар извесну дозу слободе и креативности.

Материјали и технолошке иновације свакако условљавају и нове приступе архитектури. Нови материјали попут гвоздених конструкција, армираног метода, стакла, и других нових материјала, мењају услове градње, док савремена електронска технологија почиње да се примењује на такав начин да се сада говори и о „паметним зградама“, али и „паметним градовима“, па и „паметном урбаном планирању“ (Ponton, 2016).

А резултати таквих промена постају прилично видљиви у савременим, светски познатим архитектонским достигнућима, па и у текстовима из домена архитектуре Добитница најпознатије, Прицгер награде за архитектуру, била је 2004. године Заха Хадид, и лепо је прочитати како архитекта и критичар Ђованини (Joseph Giovannini) пише о њеним архитектонским подухватима: они су „динамични и флуидни“, „лирски“, „анти-гравитациони“, „експлозивни“ и истовремено су „део околног пејзажа“ и заједно с њим стварају нови пејзаж, „простиру се у небо“, „имплодирају унутар себе“, „фрагментирају простор“ на иновативан начин, више су „порозне“ него стабилне фигуре, и сл. (The Pritzker Architecture Prize, 2004:34).

Сама Заха Хадид каже: “The meaning of fragmentation is to open the hermetic volumes, to offer porosity". Што је још важније, и у њеним речима се осликава схватање да дух времена, „комплексност и динамизам“ савременог света, његова „слојевитост“ мора да се изрази и кроз градске слике: 
„I believe that the complexities and the dynamism of contemporary life cannot be cast into the simple platonic forms provided by the classical canon, nor does the modern style afford enough means of articulation. We have to deal with social diagrams that are more complex and layered when compared with the social programs of the early modern period [...] At the same time as a restless society pushes architecture by posing a new set of characteristic problems, the new digital design tools pull architecture into an uncharted territory of opportunity." (The Pritzker Architecture Prize, 2004:21)

Остварење таквог схватања савременог друштва и културе, могуће је захваљујући и савременој технологији, јер она омогућава да „to integrate highly complex forms into a fluid and seamless whole" (ibid., 22), односно сву ту флуидност, порозност, стапање с околином, у граду је истовремено најважније место где се „немирно, комплексно друштво“ треба и сместити, па и остварити. Наравно, њени пројекти обухватају, аеродроме, велике пословне зграде, позоришта и сл., у великим и богатим срединама, што јој је свакако омогућило и остварење њених измаштаних слика савременог града.

У наведеном пригодном издању ове награде за 2004. годину, посебно је интересантан говор Томаса Прицгера. С обзиром на место доделе награде, Ст. Петерсбург, у свом кратком говору он прави аналогију између стихова Ане Ахматове, посвећених овом граду, и архитектуре Захе Хадид. С обзиром на то да се душа Русије и руског народа најбоље исказује поезијом, а Ст. Петерсбург има своју сопствену песникињу, и то је Ана Ахматова, а да се додела награде одиграла у Ермитажу, он каже да се тога дана сусрећу две велике хероине: песникиња и архитекта. Ахматова свој град види као 
готово ванземаљски (ethereal), у игри са природом и околином, вечан, и неодвојив од ње саме, са погледом на игре сенки и линије кејова Неве. Прицгер посебно цитира њене стихове: Our separation is imaginary:/ We are inseparable,/ My shadow is on your walls,/ My reflection in your canals,/ The sound of my footsteps in the Hermitage halls. (The Pritzker Architecture Prize, 2004, 19). По његовим речима, друга хероина, Заха Хадид, својом архитектуром ствара другу врсту поезије - визуелну, али су обележја њене архитектуре, игре линија и сенки, флуидност, порозност блиски песникињи.

Машта, снови и визије. Након овог кратког прегледа различитих типова текстова које сматрамо једним могућим уводом у специфичан тип лингвокултуролошког приступа заснованог на текстовима желимо да истакнемо следеће. У поетским, популарним и уметничким песмама, град се највише види кроз фрагменте, на неки начин индивидуално, кроз личне успомене, и сусрете који се памте. На скали од конкретног ка апстрактном постоје разлике од популарне до уметничке поезије, или друкчије речено, у уметничкој поезији се слике града преплићу много више са општијим питањима пролазности и вечности, спајању прошлости и будућности, док се слика града „конкретизује“ само малим детаљима, звуковима, мирисима, призорима, итд. У прозним књижевним делима, присуство архитектуре и урбане средине се претачу у слике и симболе ширег социјалног миљеа, историјских и концептуалних процеса и стања. Стручни текстови из домена архитектуре углавном, мада не увек, ограничавају поља људске маште и снова, али их не поништавају у потпуности, већ напротив, на моменте се приближавају, бар по неким елементима, поезији. Зависно од даљих раслојавања текстова и унутар овог стручног домена, можемо рећи да се и у њима могу, мање или више, наћи елемен- 
ти маштања о граду и остварењу таквих замисли.

C обзиром да је наш лингвокултуролошки поглед на исказе који се односе на снове и маштања о граду био усмерен, пре свега, на различите типове текстова, многа друга питања о градовима, текстовима о градовима и сновима и маштањима о граду, са становишта естетике (популарне културе, уметничке књижевности, архитектуре), или поређења било књижевних или некњижевних текстова на више језика и из више културних средина, могла би се даље истраживати. То би свакако било интересантно, али чак и за таква даља истраживања, сматрамо да смо дали један релевантан поглед на могуће изворе људске маште и снова о граду.

Литература:

Алфиревић, Ђ. , 2015, Razgovor o brutalizmu - intervju sa arhitektom Ljupkom Curčićem, Arhitektura i urbanizam, br. 41, str. 69-74.

Andrić, I. 2014. Na Drini ćuprija, u: Andrić, Romani, (13. izdanje), Beograd: Vulkan.

Armitage, S. 2006. 'A Vision' in: Tyrannosaurus Rex Versus The Corduroy Kid. London: Faber and Faber Ltd.

Bibri, S.E. 2018. Backcasting in futures studies: a synthesized scholarly and planning approach to strategic smart sustainable city development. Eur J Futures Res 6, 13.

Giovannini, J. 2004, in: The Pritzker Architecture Prize, 2004, The Hyatte Foundation, 34-40.

Le Normand, Brigitte. 2014. Designing Tito's Capital: Urban Planning, Modernism, and Socialism. Pittsburgh: University of Pittsburgh Press.

Markovic, M. 2011. Pre nego što sve počne da se vrti, Beograd: LOM

Nikitina, S. 2011. Forsytes' Bildungsroman: A Saga of a Place, Interdisciplinary Literary Studies, Vol. 13, No. 1/2 (Fall 2011), pp. 61-76. 
Ponton, D.M., 2016 Siracusa: Italy's smartest city? Re-branding issues from a critical ecolinguistic perspective. Language \& Ecology, 2-17.

The Pritzker Architecture Prize, 2004, The Hyatte Foundation.

Бећковић, М. Вера Павладољска. Нови Сад : Матица српска, 2003.

Секулић, И., 1977. Хроника паланачког гробља, Београд: „Вук Караџић“.

Vesna Polovina

\section{THE CITY, IMAGINATION AND DREAMS}

\section{Summary}

We analyze two types of texts: expert texts on city architecture and some literary texts, both of which use the lexemes from the "city" domain in different senses. In expert literature, where a city is the prime object of discussion, we can often find literary, poetic metaphors and expressions: city made for a man, urban networks, etc.; in literary texts, a city is a background to a human story, but also sometimes influencing the behaviour of the characters and the development of the plot, or a wide metaphor for at least some aspect of human life. It is this connection of city and human that is being explored in this analysis, showing that there is a common ground in both expert and non-expert texts when describing, imagining or dreaming about the city, as can be shown by linguistic expressions used in these two types of texts.

Key Words: city, imagination, dreams, poetry, prose, architecture. 